\title{
Die impak van afwesige vaders op adolessente dogters se psigososiale welstand
}

\author{
Fazel Ebrihiam Freeks ${ }^{a, *}$, Corinne Strydom ${ }^{b}$, Elretha Bartlett ${ }^{c}$ \\ ${ }^{a}$ Faculty of Theology, Unit for Reformed Theology of the South African Society, North-West University, \\ Potchefstroom Campus, South Africa \\ ${ }^{\mathrm{b}}$ Faculty of Social Work, School for Psycho-Social Behavioral Sciences, North-West University, Potchefstroom \\ Campus, South Africa \\ ${ }^{\mathrm{c}}$ Faculty of Social Work, North-West University, Potchefstroom Campus, South Africa
}

\section{A R T I C L E I N F O}

Article history:

Received 26 February 2015

Accepted 6 March 2015

Available online 19 August 2015

\section{Sleutelterme:}

Impak

Afwesige vaders

Adolessente dogters

Psigososiale welstand

Keywords:

Impact

Absent fathers

Adolescent girls

Psychosocial well-being

\section{O P S O M M I N G}

Daar is bevind dat baie kinders in Suid-Afrika sonder die betrokkenheid van ' $n$ biologiese vader, grootword. Die afwesigheid van 'n ouer binne die gesinsisteem bring ' $n$ vakuum in die ouerskapsrol mee en oefen 'n negatiewe invloed uit op 'n gesin se vermoë om doeltreffend te funksioneer. Met hierdie studie is die impak van afwesige vaders op die welstand van adolessente dogters ondersoek. Die studie is in twee fases verdeel. Tydens die eerste fase is semi-gestruktureerde onderhoude gevoer met ses dogters by wie die vader afwesig was. Die deelnemers se persoonlike menings van die impak wat hulle vaders se afwesigheid op hulle lewens gehad het, is in temas uiteengesit. Die kwalitatiewe data wat uit die onderhoude verkry is, is benut deurdat veranderlikes geïdentifiseer is wat in die tweede fase getoets kon word. Vir die tweede fase het 30 adolessente vraelyste ingevul. Hierdie bevindings is statisties weergegee. Die twee stelle bevindings is met mekaar vergelyk. Dit wil voorkom of die adolessente dogters ' $\mathrm{n}$ groot aantal onvervulde behoeftes het wat aan die afwesigheid van hulle vaders toegeskryf kan word. Hulle het behoefte daaraan om tyd saam met hulle vaders deur te bring en om 'n hegte band met hom op te bou. Die deelnemers het genoem dat hulle moeders beide die rol van moeder en vader vervul en deels vergoed vir die afwesigheid van hulle vaders. Die data wat deur hierdie studie ingesamel is, sal vaders help om ' $n$ beter idee te kry van hulle waarde binne die gesinstruktuur.

\section{A B S T R A C T}

It was found that many children in South Africa grow up without a biological father's involvement. The absence of a parent within a family system causes a vacuum in the parenthood role and has a negative influence on a family's ability to function efficiently. The impact of absent fathers on the well-being of adolescent girls is investigated in this study. The study was done in two phases. During the first phase semi-structured interviews were conducted with six girls where the father was absent. The participants' personal opinions of the impact their fathers' absence has on their lives were set out in themes. The qualitative data obtained from the interviews was used in that variables

\footnotetext{
* Corresponding author.
}

E-mail addresses: 10589686@nwu.ac.za (F.E. Freeks), corinne.strydom@nwu.ac.za (C. Strydom), elretha.bartlett@gmail.com (E. Bartlett).

Peer review under responsibility of Johannesburg University. 
were identified that could be tested during the second phase. For the second phase, 30 adolescents completed questionnaires. These findings were reported in statistical form. The two sets of findings were compared with each other. It seems that the adolescent girls have a huge number of unfulfilled needs that can be ascribed to the absence or their fathers. They have a need for spending time with their fathers and to bond closely with him. The participants mentioned that their mothers fulfilled both the role as the mother and as the father and partly compensate for the absence or their fathers. The data collected through this study will assist fathers in forming a better idea of their value within the family structure.

Copyright () 2015, The Authors. Production and hosting by Elsevier B.V. on behalf of Johannesburg University. This is an open access article under the CC BY-NC-ND license (http://creativecommons.org/licenses/by-nc-nd/4.0/).

\section{Inleiding}

'n Ideale gesin word beskryf as 'n groep mense wat intieme en gereelde interaksie met mekaar het, gemeenskaplike norme handhaaf en mekaar beïnvloed, ondersteun en opbou. Indien 'n ouer dus afwesig is, ontstaan 'n vakuum en oefen 'n negatiewe invloed uit op die gesin se vermoë om doeltreffend te funksioneer. Die impak van afwesige vaders op adolessente dogters se welstand word nie altyd begryp nie; daarom is hierdie studie onderneem.

\section{Agtergrond}

Die afwesige vader is tans ' $\mathrm{n}$ algemene verskynsel in SuidAfrikaanse huishoudings (Freeks, 2011). Die aantal afwesige vaders het toegeneem, van 42\% in 1996 af tot 48\% in 2011. Daar is bevind dat $51.4 \%$ van swart vaders, $38 \%$ van gekleurde vaders, $11.5 \%$ van Indiër-vaders en $19.4 \%$ van wit vaders afwesig is in hul kinders se lewens (Holborn \& Eddy, 2011; SAIRR, 2013). Binne die ouderdomskategorie 15-49 jaar is ongeveer $54 \%$ van mans vaders, terwyl $50 \%$ geen kontak met hul kinders het nie. Dit het aggressiewe gedrag by kinders tot gevolg, wat gepaard gaan met talle ander probleme (FAMSA, 2012; SAIRR, 2013). Die teenwoordigheid van ' $\mathrm{n}$ vader dra by tot kognitiewe ontwikkeling, intellektuele funksionering en skoolprestasie (Holborn \& Eddy, 2011).

In Suid-Afrika is daar min geleenthede vir mense om 'n inkomste te verdien in die gebiede waar hulle kan bekostig om te woon. As gevolg daarvan is dit vir 'n groot aantal vaders nie moontlik om saam met hulle kinders te leef en om hulle te onderhou nie (Holborn \& Eddy, 2011; Madhavan, Townsend, \& Garey, 2008; Smit, 2004; Steyn, 1993). Mandara, Murray, and Joyner (2005) voer aan dat die nalatenskap van apartheid, werkloosheid, armoede en ongelykheid in postapartheid Suid-Afrika, geslagsongelykheid en MIV/VIGS, 'n nadelige impak het op gesinspraktyke en die betrokkenheid van vaders by hul kinders se lewens.

\section{Probleemstelling}

Kinders gebore sedert 1991 is aansienlik minder geneig om ondersteuning van hul vaders te ontvang as diegene wat voor 1991 gebore is (Madhavan et al., 2008). Hierdie afname kan toegeskryf word aan die feit dat die werksituasie van mans in Suid-Afrika versleg het. Daar is nie meer so baie geleenthede vir mans om in dieselfde gebied te werk as waar hul gesin woon nie (Holborn \& Eddy, 2011; Madhavan et al., 2008). Daar word veronderstel dat kulturele verwagtinge van vaderskap en die aard van die sosiale verhouding tussen vader en kind die aard van vaders se betrokkenheid ten grondslag lê (Madhavan et al., 2008).

Die afwesigheid van ' $n$ ouer binne die gesinsisteem laat ' $n$ vakuum in die ouerskapsrol ontstaan en het 'n negatiewe invloed op 'n gesin se vermoë om doeltreffend te funksioneer. Aanpassings moet gemaak word binne die ouer-kindsisteem (DuBois \& Miley, 2010). Volgens Almond (2006) speel vaders ' $n$ al belangriker rol in kinders se lewens namate hulle ouer word. Dit wil voorkom of jong kinders wat goed versorg word, min geraak word deur die afwesigheid van 'n vaderfiguur. In teenstelling hiermee spreek baie ouer kinders die behoefte uit aan gereelde kontak met 'n pa (Freeks, 2013). 'n Afwesige vader kan 'n negatiewe effek op ouer kinders se selfbeeld en gedrag hê (Almond, 2006; Freeks, 2011; SAIRR, 2013).

In 'n persoonlike onderhoud met die direkteur van 'n welsynsorganisasie in die Noordwes Provinsie, is genoem dat adolessente dogters wat sonder ' $n$ vaderfiguur grootword, groter behoefte aan aanvaarding en toenadering tot die teenoorgestelde geslag het. Hierdie dogters is dikwels bereid om uit hul pad te gaan om aanvaar te word en raak op 'n jonger ouderdom seksueel aktief. Dit dra indirek by tot die kwessie van tienerswangerskappe (Freeks \& Lotter, 2009:522; Grainger, 2004:133; Oelofse, 2013). Hulle mag vlerkslepende gedrag en ander aandagsoekende gedrag openbaar, maar dit terselfdertyd moeilik vind om romantiese verhoudings in stand te hou (vgl. Bartlett, 2013; Holborn \& Eddy, 2011).

In 'n studie wat gedoen is deur Mandara et al. (2005), is bevind dat vaderlose dogters van 'n lae-inkomstegroep, 
hulleself as meer manlik beskou as dogters met betrokke vaders. Hulle is meer geneig om eienskappe soos onafhanklikheid en selfgelding te ontwikkel vanweë die feit dat hulle nie gewoond is aan 'n beskermende vaderfiguur wat hulle in tye van nood bystaan nie (Cruz et al. 2011; Green, 1976:72; Goodsell \& Meldrum, 2010). Hierdie verskille kan hoofsaaklik toegeskryf word aan die omgewingseise van armer gemeenskappe en die afwesigheid van vaders se tradisionele sosialiseringstrategieë in vaderlose huishoudings. Alhoewel die ontwikkeling van meer manlike eienskappe soos onafhanklikheid en selfgelding nie noodwendig nadelig is nie, het die gebrek aan 'n hegte verhouding met ' $n$ pa nadelige emosionele implikasies tot gevolg (Grainger, 2004; Mandara et al. 2005).

Ma's wat hul dogters self grootmaak, sonder die ondersteuning van 'n man, word deur 'n unieke stel uitdagings in die gesig gestaar. Ouers sonder lewensmaats is geneig om die volgende eienskappe te openbaar: frustrasie, 'n gevoel van mislukking, skuldgevoelens en gevoelens van ambivalensie tussen enkelouer en kind. Hierdie ouers voel dikwels onbevoeg en nie in staat om met hul kinders te identifiseer nie. Dit het indirek 'n nadelige impak op die ontwikkeling van die kind (Adams, Milner, \& Schepe, 1984; Fagan, Palkovitz, Roy, \& Farrie, 2009; Goodsell \& Meldrum, 2010).

Om bogenoemde situasie verder te kompliseer het adolessensie die reputasie om 'n onstuimige tydperk binne die gesinsisteem te wees. Konflik neem toe namate die adolessent na toenemende onafhanklikheid streef. Die kwessies waardeur adolessente in die gesig gestaar word, hou verband met seksualiteit, romantiese verhoudings, heronderhandeling van gesinsverhoudings, die neem van besluite rakende toekomstige beroepe en die besturing tussen balansering van sosiale en gesinsnorme (Collins, Jordan, \& Coleman, 2010; Dinkmeyer, Mckay, Mckay, \& Dinkmeyer, 1998; Pacholok \& Gauthier, 2010; Papalia, Olds, \& Feldman, 2009). Take wat tydens adolessensie van belang is, sluit die volgende in: leer om ander te vertrou, die vorming van 'n stabiele identiteit en die oplos van belangrike lewensvrae. Intimiteit, verhoudings, moraliteit, portuurgroep-assosiasies en lewensdoelwitte is belangrik namate jongmense nuwe rolle aanneem en poog om hul lewensrigting te bepaal (Collins et al. 2010).

Die navorsingsvraag vir hierdie studie is die volgende:

Wat is die impak van afwesige vaders op adolessente dogters se psigososiale welstand?

\subsection{Doelstelling}

Die doelstelling is om vas te stel wat die impak van die afwesigheid van 'n vader op adolessente dogters se psigososiale welstand is.

\section{Definisie van konsepte}

\subsection{Impak}

Dit is die "invloed of uitwerking wat iets (iemand) op iets (iemand) anders het" (HAT, 1994).

\subsection{Afwesige vaders}

Dit verwys na gesinne waar daar geen vaderfiguur is nie (Adams et al. 1984; Freeks, 2011; Freeks \& Lotter, 2009) of waar die vader óf uit vrye keuse óf weens onvermoë nie sy vaderskapsrol nakom nie (DuBois \& Miley, 2010).

\subsection{Adolessensie}

Die oorgangsperiode tussen die kinder-en volwasse jare, waartydens jongmense fisies en seksueel volwasse raak. Dit duur gewoonlik van die ouderdom 12 af tot die laattienerjare (Papalia et al. 2009; Zastrow \& Kirst-Ashman, 2013).

\subsection{Psigososiale welstand}

Dit behels die geluk en lewenstevredenheid (Papalia et al. 2009) op psigologiese en maatskaplike funksioneringsvlakke van die mens. Die psigologiese vlak verwys na die interne prosesse van die mens, soos sy denkpatrone en emosies en die maatskaplike vlak verwys na die sosiale omgewing waarbinne die individu hom bevind en die netwerke waarvan hy deel uitmaak (Van Wormer \& Davis, 2008).

\section{Literatuuroorsig}

Die temas wat ondersoek is, is afwesige vaders, adolessente dogters en psigososiale welstand. ' $n$ Leemte in die huidige literatuur is die gebrek aan navorsing oor die impak van afwesige vaders binne die Suid-Afrikaanse konteks. Talle internasionale studies is reeds onderneem, maar hierdie data het nie betrekking op Suid-Afrika met sy unieke geskiedenis en houdings teenoor vaderskapspraktyke nie. Daar is verder ook ' $n$ gebrek aan statistiese data rakende die persentasie vaderlose kinders wat met gemeenskaplike probleme worstel.

Databasisse en vaktydskrifte wat geraadpleeg is, is EBSCO Host Web, Sabinet Online, Google Scholar, SA ePublications en Science Direct. Plaaslike en internasionale bronne op die gebied van Maatskaplike Werk, Sielkunde en Opvoedkunde is benut.

\section{Navorsingsmetodologie}

\subsection{Ontwerp}

Die verkennende gemengdemetode-benadering is gevolg. Volgens Ivankova, Creswell, and Plano Clark (2007) word die verkennende paradigma gebruik wanneer die navorser eers nodig het om ' $n$ onderwerp deur middel van kwalitatiewe data te verken voordat dit kwantitatief gemeet of getoets word. Dit is geskik wanneer 'n onderwerp bestudeer word waaroor daar min teorie bestaan of wanneer die navorser nie weet watter konstrukte geskik is of hoe om belangrike veranderlikes te toets nie. Die gemengdemetode-benadering, soos in hierdie geval, samel beide kwalitatiewe en kwantitatiewe data in sodat dit aan die einde geïntegreer kan word (Delport \& Fouche, 2011). Hierdie benadering is 
gevolg om groter voordeel te verkry (Monette, Sullivan, \& DeJong, 2008). Die navorser het kwalitatiewe data ingewin en hierdie data gebruik om oor te gaan tot ' $n$ tweede, kwantitatiewe fase. Deur die ontwikkeling van ' $n$ instrument is daar op die resultate van die kwalitatiewe fase gebou. Die kwalitatiewe data is benut deurdat veranderlikes geïdentifiseer is wat in die tweede fase getoets kon word (Creswell \& Plano Clark, 2007). Die proses wat gevolg is, kan soos volg voorgestel word: graad 10 en 11 klasse mondelings bekendgemaak. Na afloop van die aanhoor van die studie het leerlinge wat kwalifiseer vir die studie en wat gewillig was om daaraan deel te neem, die geleentheid gekry om hulle name op 'n vorm aan te dui. Uit die 200 leerlinge wat hul name op die vorm aangebring het, het die navorser elke vyfde naam geselekteer. Die 40 leerlinge wie se name getrek is, is uitgenooi om tydens pouse in een van die klaskamers bymekaar te kom ten einde die spesifieke vraelys te voltooi. Uit die 40 leerlinge wat

\begin{tabular}{lllllll}
\hline $\begin{array}{l}\text { Samel } \\
\text { kwalita-tiewe } \\
\text { data in }\end{array}$ & $\begin{array}{l}\text { Anali-seer } \\
\text { kwalita-tiewe } \\
\text { data }\end{array}$ & $\begin{array}{l}\text { Kwalita-tiewe } \\
\text { resultate }\end{array}$ & $\begin{array}{l}\text { Ontwikkel } \\
\text { instrument } \\
\text { of teorie om } \\
\text { te toets }\end{array}$ & $\begin{array}{l}\text { Samel } \\
\text { kwanti-tatiewe } \\
\text { data in }\end{array}$ & $\begin{array}{l}\text { Analiseer } \\
\text { kwanti-tatiewe } \\
\text { data }\end{array}$ & $\begin{array}{l}\text { Kwantita-tiewe } \\
\text { resultate }\end{array}$ \\
\hline Creswell \& Plano Clark, 2007 & & & & Interpre-tasie \\
\hline
\end{tabular}

\subsection{Deelnemers}

Twee stelle deelnemers is gebruik.

\subsubsection{Fase 1}

In die eerste, kwalitatiewe fase het die navorser doelgerig ' $n$ klein aantal deelnemers geïdentifiseer wat omvattende inligting oor die onderwerp kon verskaf (Creswell \& Plano Clark, 2007). Die navorser het ses skoliere wat sonder 'n vader grootgeword het, by 'n hoërskool in die Noordwes Provinsie geïdentifiseer. $\mathrm{Na}$ afloop van 'n studie rakende maatskaplike probleme wat voorkom binne verskeie hoërskole in die Noordwes Provinsie, is daar bevind dat die spesifieke hoërskool waar die studie uitgevoer is, 'n groot hoeveelheid vaderlose leerlinge het. Die kwessie van afwesige vaders is reeds geïdentifiseer as een van die ernstigste probleme binne die spesifieke skool, wat aanleiding gee tot talle ander probleme. Daar is kontak gemaak met die skoolhoof, wat gehelp het met die identifisering van dogters wat geskik sou wees vir hierdie studie. Onderhoude is met sleg 'n klein aantal skoliere gevoer vanweë die feit dat dataversadiging gou bereik is.

Die eienskappe waaraan die deelnemers voldoen het, is die volgende:

- Geslag: vroulik

- Ouderdom: 16-18 jaar

- Ras: Kleurling of swart

- Grootgeword sonder 'n vader

- Die deelnemers is Engels of Afrikaans magtig.

\subsubsection{Fase 2}

Vir die tweede fase van die navorsing, het die navorser 30 dogters gekies op wie vraelyste afgeneem is. Die deelnemers was verteenwoordigend van vaderlose adolessente dogters binne die spesifieke hoërskool. Ewekansige steekproeftrekking is benut sodat elke persoon in die populasie ' $n$ gelyke kans gehad het om gekies te kon word (Creswell \& Plano Clark, 2007). Die ondersoekgroep het aan dieselfde kenmerke voldoen as die deelnemers wat tydens fase 1 gebruik is. Die navorser het die studie aan verskeie geselekteer is, het 34 opgedaag. Uit die 34 voltooide vraelyste is vier foutief ingevul. Daar was dus 'n totaal van 30 vraelyste wat vir die tweede fase van die studie benut kon word.

\subsection{Meetinstrumente}

\subsubsection{Fase 1}

Navorsers maak gebruik van semi-gestruktureerde onderhoude ten einde ' $n$ gedetailleerde prentjie te verkry van 'n deelnemer se oortuigings, persepsies of ervarings rakende 'n spesifieke onderwerp (Gaskell, 2000; Greeff, 2011; Steyn \& Lotter, 2006). Semi-gestruktureerde onderhoude is veral geskik wanneer die navorser belangstel in kompleksiteit en wanneer die onderwerp kontroversieel of persoonlik is. Inligting word verkry wat nie op enige ander manier ingesamel sal kan word nie (Nieuwenhuis, 2007a). Hierdie onderhoude word gelei deur 'n stel voorafbepaalde vrae wat as riglyn dien. Oopeinde-vrae moet gestel word om die deelnemers toe te laat om hulle vryelik uit te druk (Greeff, 2011). Een onderhoud is met elkeen van die deelnemers gevoer.

\subsubsection{Fase 2}

Daar is van ' $n$ groepgeadministreerde vraelys gebruik gemaak. Hierdie vraelys is deur die navorser self opgestel. Die vraelys is gegrond op die temas wat tydens fase 1 na vore getree het. Die voordele van groepgeadministreerde vraelyste is dat die navorser teenwoordig is om bepaalde instruksies te gee en moontlike onsekerhede uit te klaar. Tyd en kostes word gespaar wanneer 'n groep respondente gelyktydig hanteer word en die hele groep word aan dieselfde stimulus blootgestel (Delport, 2005).

Die vraelyste is tydens pouse in een van die klaskamers van die spesifieke skool waar die studie uitgevoer is, voltooi. 'n Hele aantal beginsels moet deur die navorser in gedagte gehou wanneer hy/sy self 'n vraelys opstel. Sinne moet byvoorbeeld helder en bondig wees, elke vraag moet slegs een gedagte bevat en elke vraag moet verband hou met die doel van die vraelys. Leidende en negatiewe vrae moet vermy word en voorkeur moet gegee word aan korter vrae (Delport, 2005). 


\subsection{Prosedures}

Met die navorsing is die volgende stappe uitgevoer:

\subsubsection{Fase 1}

Identifiseer 'n navorsingsonderwerp.

Kry die nodige toestemming.

Ontwikkel die steekproef

Onderneem 'n voorondersoek.

Beplan vir die eerste fase: semi-gestruktureerde onderhoude met deelnemers.

Voer onderhoude waartydens kwalitatiewe data ingesamel word.

Analiseer die kwalitatiewe data volgens temas.

\subsubsection{Fase 2}

Gebruik die kwalitatiewe resultate om 'n vraelys op te stel.

Kies 'n steekproef vir die tweede fase.

Onderneem 'n voorondersoek.

Vraelys word voltooi.

Data word aan 'n statistikus gegee, wat dit dan analiseer. Interpreteer resultate en vergelyk met dié van die eerste fase.

Skryf navorsingsverslag.

\subsection{Dataverwerking}

\subsubsection{Fase 1}

Data is binne die eerste fase verwerk deur die analise van temas wat herhaaldelik na vore getree het, soos voorgestel deur Creswell en Plano Clark (2007). Daar is dus van narratiewe analise gebruik gemaak (Nieuwenhuis, 2007b).

\subsubsection{Fase 2}

Die data is met die hulp van 'n sigblad deur die navorser self verwerk. 'n Statistikus het gehelp met die opstel van grafieke en die interpretasie van sommige van die vrae. Die data word deur middel van statistiek, grafieke en tabelle in die navorsingsverslag weergegee. 'n Groot voordeel van die grafiese voorstelling van data is dat die belangrikste kenmerke van die verspreiding onmiddellik waargeneem kan word, soos hoe simmetries of skeef die verspreiding is (Pietersen \& Maree, 2007).

\subsection{Etiese aspekte}

'n Etiese aspek wat by hierdie studie ter sprake is, is die vermyding van emosionele skade aan deelnemers (Strydom, 2005). Die tipe inligting wat tydens die studie ingesamel is, is persoonlik en emosioneel van aard. Die moontlikheid het bestaan dat ou wonde oopgekrap kon word en dat deelnemers moontlik ontstel kon word daardeur.

Hierdie aspek is ondervang deurdat die deelnemers voor die aanvang van die studie ten volle ingelig is oor die volgende aspekte: die doel van die ondersoek, prosedures wat gevolg sou word en die moontlike voordele en nadele wat deelname aan die studie vir hulle sou inhou (Strydom, 2005). Die deelnemers is die geleentheid gegun om na afloop van die aanhoor van bogenoemde inligting, vrylik te besluit of hulle aan die studie wou deelneem of nie. Hulle was vry om hulle tydens enige fase van die studie te onttrek. Selfs al het die skoolhoof gehelp met die identifisering van deelnemers, het die deelnemers in geen geval verplig gevoel om aan die studie deel te neem nie. Die navorser het voor die aanvang van die studie die deelnemers ingelig oor hul reg om te onttrek van die studie. Daar is aan die deelnemers beklemtoon dat onttrekking van die studie geen nadelige gevolge vir hulle sal inhou nie. Na die ontvang van hierdie inligting was daar wel deelnemers wat besluit het om te onttrek.

Tydens die keuringsproses van deelnemers het die navorser die skoolhoof versoek om slegs leerlinge te identifiseer wat emosioneel stabiel is en vir wie deelname aan die studie nie nadelige gevolge sou inhou nie. Privaatheid is verseker deurdat die onderhoude in die personeelkamer van die spesifieke skool gevoer is.

Die deelnemers het binne die ouderdomskategorie 16 tot 18 jaar geval. Aangesien 'n groot persentasie deelnemers jonger as 18 jaar was en dus nie die volle kapasiteit gehad het om toestemming te verleen nie, is omsendbriewe aan hul ouers/ voogde uitgereik waar die doel en prosedure van die studie ten volle verduidelik is. Na die ontvang van hierdie inligting is toestemming van die ouers/voogde verkry deur die ondertekening van die bestaande brief.

Ontlontingsessies is deur die navorser na afloop van elke individuele onderhoud verskaf om hulle die geleentheid te gee om deur hul emosionele ervarings te werk (Strydom, 2005).

Vertroulikheid is gehandhaaf deurdat geen inligting wat tydens die onderhoude ingewin is, aan ander persone oorgedra is nie. Vraelyste is anoniem ingevul. Die data word anoniem, volgens ' $n$ kode-stelsel in die navorsingsverslag weergegee. Die navorser het gepoog om te alle tye so objektief moontlik te bly.

Die navorser het toestemming ontvang om die studie by die spesifieke skool uit te voer, deur middel van die skryf van ' $n$ toestemmingsbrief aan die skoolhoof. Die deelnemers met wie individuele onderhoude gevoer is, is versoek om omsendbriewe deur hul ouers te laat onderteken waardeur hulle ouers toestemming aan hulle verleen om aan die studie deel te neem.

Etiese toestemming is deur die Etiekkomitee van die Noordwes-Universiteit verleen onder die projek: NWU-000311-A1; COMM-SURF.

\section{Geldigheid en getrouheid}

\subsection{Vertrouenswaardigheid}

Tabel 1 bevat inligting rakende die standaarde wat toegepas is in die navorsing om vertrouenswaardigheid te verseker.

\section{Bevindinge}

\subsection{Fase 1}

Die bevindinge van die onderhoude is weergegee deur die belangrikste temas wat tydens die individuele onderhoude 
Tabel 1 - Vertrouenswaardigheid.

\begin{tabular}{|c|c|c|}
\hline Standaard & Strategie & Kriteria \\
\hline Waarheidsgetrouheid & Geloofwaardigheid & $\begin{array}{l}\text { Die navorser het eers 'n verhouding met die deelnemers opgebou. } \\
\text { Triangulasie van data van onderhoude en vraelyste is gedoen. } \\
\text { Die studieleiers het gekyk of die transkribering en temas en subtemas } \\
\text { ooreenkom. }\end{array}$ \\
\hline Toepaslikheid & Oordraagbaarheid & $\begin{array}{l}\text { Metode van steekproefneming is duidelik omskryf. } \\
\text { Die aantal onderhoude is bepaal deur dataversadiging. } \\
\text { Die kwalitatiewe en kwantitatiewe resultate is volledig beskryf. }\end{array}$ \\
\hline Konsekwentheid & Vertroubaarheid & $\begin{array}{l}\text { Etiese stappe is volledig uitgevoer. } \\
\text { Kodering en herkodering is met die hulp van studieleiers gedoen. }\end{array}$ \\
\hline Neutraliteit & Bevestigbaarheid & $\begin{array}{l}\text { Triangulasie is van die twee stelle deelnemers se resultate gedoen. } \\
\text { Daar is akkuraat verslag gelewer oor die inhoud. }\end{array}$ \\
\hline
\end{tabular}

uitgestaan het, te bespreek. Literatuurkontrole en direkte aanhalings is benut. Die bevindinge weerspieël die deelnemers se persoonlike menings oor die impak wat hul vaders se onbetrokkenheid by hul lewens op hulle gehad het. Die temas kan soos volg voorgestel word: Figuur 1.

\section{Tema 1: Kommer oor biologiese moeder}

Vier van die deelnemers noem dat die lewe makliker vir hul biologiese moeders sou gewees het as hulle vaders in hul lewens betrokke was. Hulle noem dat hulle bekommerd is oor die hoeveelheid stres wat hul moeders op 'n daaglikse basis ondervind.
Subtema 1.1: Finansiële las: Die finansiële las wat afwesige vaders agterlaat, is veral van belang binne gemeenskappe waar armoede aan die orde van die dag is. Daar is minder geld beskikbaar wat aan die versorging van die kinders bestee kan word (Lamb, 2010). Adams et al. (1984) beklemtoon dat kinders van enkelmoeders veel meer geneig is om in armoede te leef as kinders met albei ouers.

Twee van die deelnemers noem dat hulle nou, as gevolg van hulle vaders se onbetrokkenheid, finansieel swaarder dra. Hulle is van mening dat die finansiële las binne die gesin ligter sou gewees het as hul biologiese vaders betrokke was. Die twee deelnemers se beskrywings is soos volg:

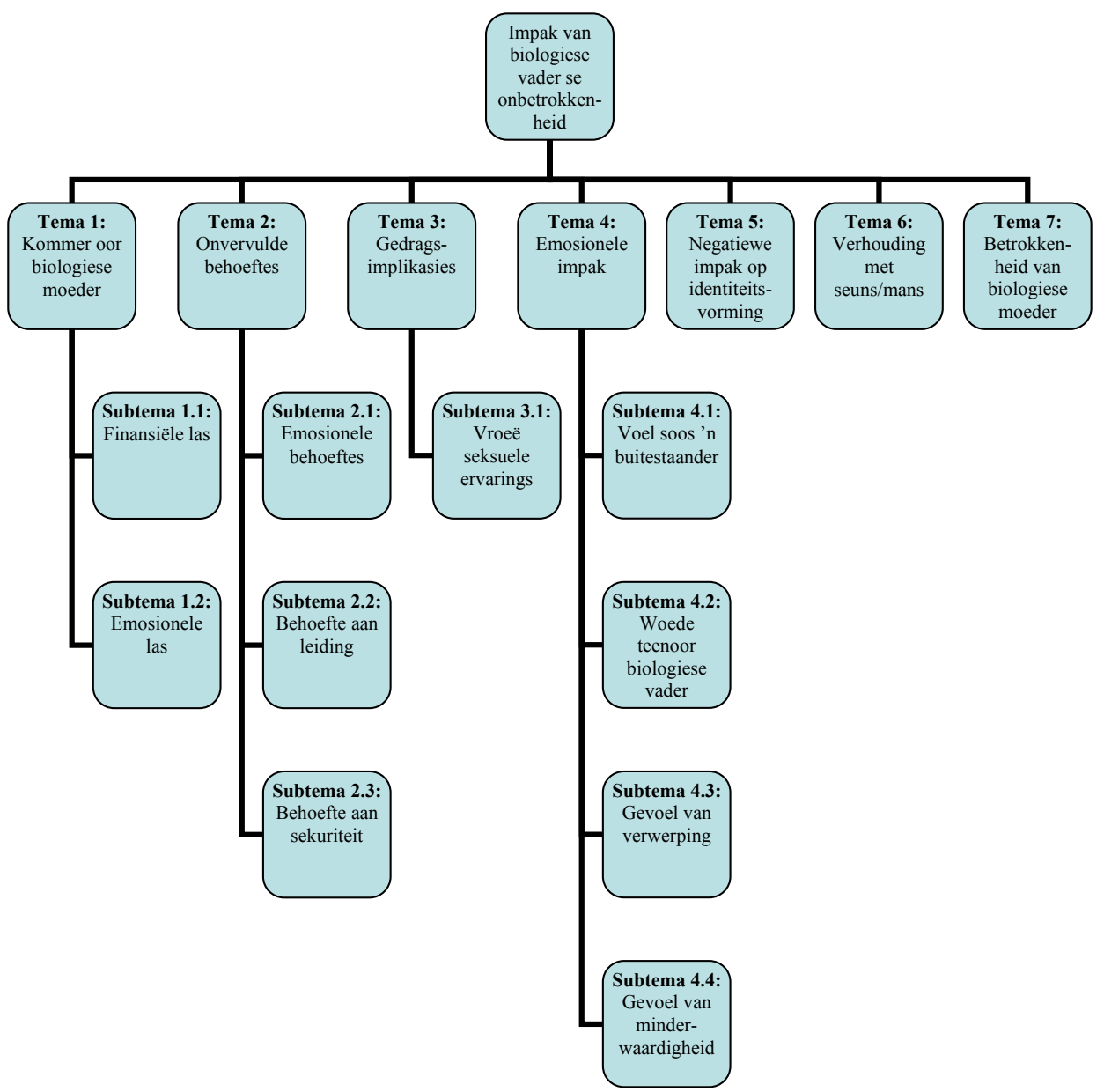

Figuur 1 - Temas van semi-gestruktureerde onderhoude. 
C: "My ma help wanneer ek goed nodig het. As daar nie daarvoor geld is nie, dan maak sy altyd 'n plan."

D: "I see my mom suffer ... there's never enough money."

Subtema 1.2: Emosionele las: Volgens Lamb (2010) ervaar enkelmoeders groot hoeveelhede emosionele spanning. Hulle is meer geneig om sosiaal geïsoleerd te voel en word dikwels blootgestel aan sosiale afkeuring. Die enkelmoeder moet al die versorgingsverant woordelikhede, sonder die ondersteuning van 'n huweliksmaat, self dra. Daar is niemand wat haar kan help met die neem van moeilike besluite nie. Sy kan moontlik worstel met skuldgevoelens vanweë die feit dat daar nou minder energie en tyd beskikbaar is om aan die kinders af te staan (Lamb, 2010).

Drie van die deelnemers in die studie noem dat hulle moeders nou beide ' $n$ moederlike en vaderlike rol moet vervul. Die eie woorde van twee deelnemers is soos volg:

C: "My ma het ons baie gehelp; sy is soos 'n ma en 'n pa." "Nou moet my ma ons alleen grootmaak, swaarkry en swaar dra."

E: "She's (mother) like my mom and my father at the same time ... she's the tree that holds this family together ... She's under a lot of pressure right now."

Die feit dat hulle biologiese moeders ' $n$ groot hoeveelheid stres ondervind, het indirek 'n negatiewe impak op die deelnemers se gemoed. Hulle is bekommerd oor hul biologiese moeders en worstel dikwels met skuldgevoelens oor die hoeveelheid energie wat hulle van hul moeders verg.

\section{Tema 2: Onvervulde behoeftes}

Die onvervulde behoeftes blyk die grootste leemte te wees wat ' $n$ biologiese vader se onbetrokkenheid tot gevolg het. Drie subtemas val onder hierdie hooftema.

Subtema 2.1: Emosionele behoeftes: Die eerste subtema, emosionele behoeftes, kan egter verder onderverdeel word. Dit word soos volg voorgestel: Figuur 2

a) Liefde: Freeks, 2004 en Green (1976) noem dat 'n empatiese en warm houding teenoor ' $n$ kind goeie vaderskap ten grondslag lê. As vaders aanvaar dat hul kinders mense in hul eie reg is en nie te veel vooropgestelde idees het oor die tipe mense wat hulle moet word nie, sal hulle suksesvol wees binne hul rol as vader.

Op die vraag: "Wat was dit wat jy nog altyd van jou pa wou gehad het en nooit gekry het nie?" is van die antwoorde soos volg:

A: "Liefde, die wete dat hy omgee vir my."

D: "Support and love"

E: "Love ... I always wanted to be his dearest little girl, to have a special place in his heart."

Dit is duidelik dat die deelnemers sterk behoefte het aan liefde van hul biologiese vaders. Hulle het behoefte daaraan om 'n verhouding met hom op te bou en om tyd saam met hom deur te bring. Daarmee saam het sommige van die deelnemers behoefte daaraan om hul eie liefde teenoor hul biologiese vaders te verklaar. Op die vraag: "As jy nou iets vir

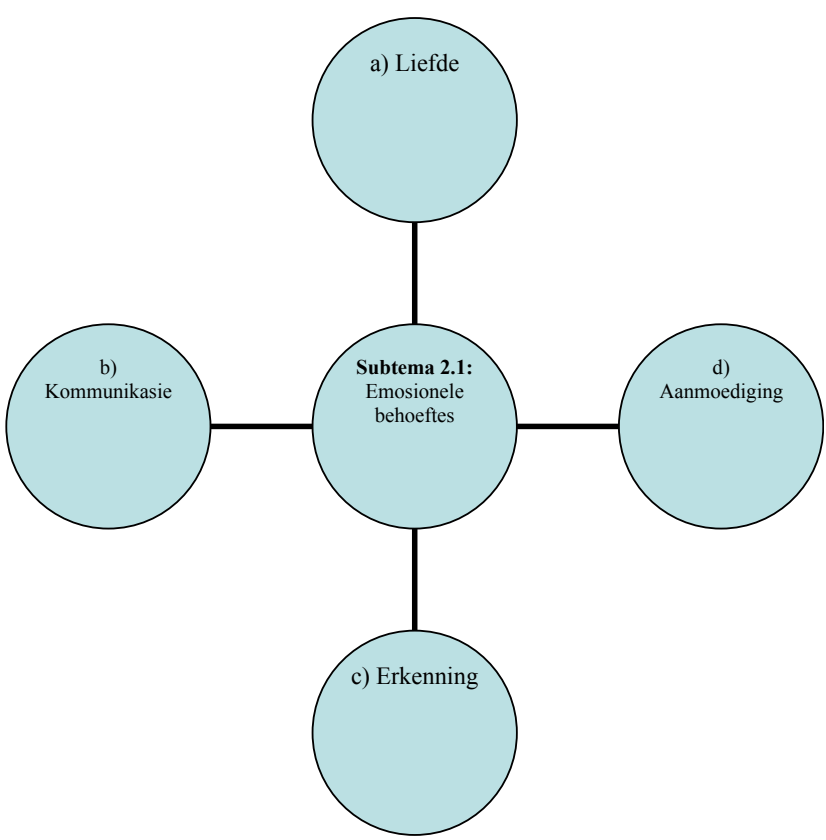

Figuur 2 - Emosionele behoeftes.

jou pa kon sê, wat sou jy sê?" antwoord twee van die deelnemers soos volg:

A: "Dat ek nie kwaad is vir hom nie, dat ek baie lief is vir hom. Dat ek graag wou hê dat hy daar moes wees in my lewe."

C: "Ek is lief vir pa. Jy moenie ons harte so seer maak nie."

Een deelnemer is van mening dat dit eendag vir haar moeilik sal wees om te weet of sy die regte man gevind het. Sy skryf dit toe aan die feit dat sy geen verwysingsraamwerk sal hê van wat dit beteken om deur 'n man liefgehê te word nie.

Kinders en adolessente wat hegte, ondersteunende verhoudings met beide hul ouers het, is meer geneig om sielkundige welstand te geniet as kinders wie se verhoudings met hul ouers - moeders of vaders - minder bevredigend is. 'n Goeie vader kan beskryf word as iemand wat in staat is daartoe om ' $\mathrm{n}$ gesonde ouer-kindverhouding in stand te hou. Die sukses van ' $n$ vader kan dus nie toegeskryf word aan sy intelligensievlak of manlike eienskappe nie, maar eerder aan die emosionele betrokkenheid in sy kind se lewe (Lamb, 2010).

b) Kommunikasie: Uit die navorsing blyk dit duidelik dat die deelnemers sterk behoefte het daaraan om in gesprek te tree met hul biologiese vaders. Een van die deelnemers noem dat sy graag die probleme in haar lewe met haar biologiese vader sou wou deel. Op die vraag: "Hoe wou jy gehad het dat jou pa meer betrokke moes wees?" antwoord van die deelnemers soos volg:

A: "Ek wou met hom gesels het. Dat hy in die nag stories vertel ... my vertel van die lewe, die Apartheid van vorige jare." 
B: "Ek sou gelike het as hy elke dag by ons kon gebly het, 'n verhouding met hom gehad het soos ander dogters met hul pa's het ... hulle is daarso en gesels."

E: "I want to talk to him; knowing that I can share anything with him."

c) Erkenning: Dit is duidelik dat die deelnemers sterk behoefte het aan erkenning van hul biologiese vaders. Hulle wil hê dat hul vaders waarde aan hulle moet heg. Een van die deelnemer sê die volgende:

F: "Sometimes my father comes to Potch, but he won't even come to greet me ... He doesn't even reply when I send him messages on facebook. He ignores me when he sees me, doesn't even look at me, doesn't accept that I'm his child."

Deelnemer C kyk af en vroetel met haar vingers, terwyl sy vertel dat haar biologiese vader nooit vir haar kom groet nie. Die feit dat haar vader haar bestaan ontken, het ' $n$ negatiewe impak op haar selfbeeld. Sy sê die volgende:

C: "Ek wil hê hy (biologiese vader) moet by my wíl wees; dat ek genoeg vir hom beteken om daar vir my te wil wees ... My pa moet sê: 'Dis my kind."'

d) Aanmoediging: Adolessente het aanmoediging en respek van hul ouers nodig. Hulle wil hê dat hul ouers hul pogings moet raaksien, in hulle moet glo en waardering teenoor hulle moet uitspreek (Dinkmeyer et al. 1998).

Party van die deelnemers het behoefte daaraan dat hulle vaders hulle in hul daaglikse aktiwiteite moet motiveer. Twee van die deelnemers sê die volgende:

A: “' $n$ Pa het ' $n$ belangrike rol in ' $n$ tienermeisie se lewe. Hy sorg vir haar en moet terselfdertyd opbou en motiveer."

E: "I want my father to boost and motivate me as my mother always does."

Subtema 2.2: Behoefte aan leiding: Die opvoedingsrol wat ' $n$ vader vervul, word beskou as een van sy tradisionele rolle. Daar word van mans verwag om die standaarde en verwagtinge van die buitewêreld aan hulle gesinne terug te rapporteer (Green, 1976).

Op die vraag: "Wat is die waarde van pa's in tienerdogters se lewens?" antwoord van die deelnemers soos volg:

A: "Hulle moet ons aanmoedig om Bybel te lees en leiding en raad aan ons gee. Hulle moet 'n voorbeeld vir ons wees." C: "Hulle vertel ons van die wêreld, wat ons nie moet doen nie en gee raad, soos dat ons nie by seuns betrokke moet raak nie ... Daar is party goed wat pa's meer verstaan, veral wanneer dit by seuns kom ... vertel van verkeerde en regte dinge in haar verhouding met seuns. As ek my ma daaroor sou vra, sal sy my afjak en afraai om betrokke te raak by hulle."

Dit is duidelik dat die deelnemers geestelike leiding van hul vaders verlang. Hulle wil hê dat hul vaders gesonde waardes vir hulle moet aanleer. Die deelnemers wil almal graag hê dat hul vaders 'n goeie voorbeeld vir hulle moet stel. Hulle het behoefte daaraan dat hul vaders hulle moet aanmoedig om goeie keuses in hul lewens uit te oefen. Verder het hulle behoefte daaraan dat hul vaders inligting rakende seuns in die algemeen met hulle moet deel. Twee van die deelnemers gaan verder deur die volgende te sê:

A: "Ek wil maniere en lesse by hom (vader) leer ... wat jy moet doen in die lewe."

F: "I wanted us (my father and me) to teach each other. I want to learn from him, but not just that, I want him to learn from me."

Die deelnemers verlang ' $n$ positiewe rolmodel. Deur vaders se lewenswyse moet hulle ' $n$ goeie voorbeeld vir hulle kinders wees (Chideya \& Williams, 2013). Volgens Lamb (2010) is kinders meer geneig om hul vaders se goeie voorbeeld te volg wanneer hulle van hom hou en wanneer hulle 'n hartlike en positiewe verhouding met hom het.

Subtema 2.3: Behoefte aan sekuriteit: 'n Groot persentasie van die deelnemers wil net hê dat hul vaders teenwoordig moet wees in hul lewens, selfs al is hy nie ' $n$ betrokke vader nie. Die wete dat hul vaders teenwoordig is, sou hulle gehelp het om veilig en geborge te voel. Op die vraag: "Wat was dit wat jy nog altyd van jou pa wou gehad het en nooit gekry het nie?" antwoord 'n paar van die deelnemers die volgende:

D: "His presence, to be there for us."

E: "The comfort of having him around me, to know that he is there. Knowing that he is my father." "I wish he was always with me, to hold my hand through the worst and the good."

Een deelnemer gaan verder deur die volgende te sê:

B: "Ek sou graag my ouers saam wou sien ... Ek sou graag saam met my pa wil sit en boek lees, dat hy net daar gewees het."

Dit is duidelik dat ' $n$ vader se teenwoordigheid dikwels ' $n$ gevoel van sekuriteit by sy dogter laat ontstaan. Die fisiese teenwoordigheid van 'n vader skep stabiliteit, sekerheid, verantwoordelikheid en volwassenheid by volwasse kinders (Ford, Nalbone, Wetcher, \& Sutton, 2008; Freeks \& Lotter, 2009; Krampe \& Newton, 2006; Sieber, 2008).

Tema 3: Gedragsimplikasies

Subtema 3.1: Vroeë seksuele ervarings: Alhoewel nie een van die deelnemers melding van enige vroeë seksuele ervarings maak nie, noem een van die deelnemers dat sy ' $n$ hele paar dogters ken wat sonder 'n vader grootgeword het en wat vroeg in hul lewens swanger geraak het. Sy skryf dit toe aan die feit dat hierdie dogters nooit die liefde ontvang het wat hulle in ' $n$ vader verlang het nie en dat hulle dan liefde by ander mans gaan soek. Die deelnemer sê die volgende:

F: "Girls without fathers often look for love in the wrong places. A father should show his daughter what love from a man really means." 
Vaderlose dogters is meer geneig om emosioneel onvervuld te voel. Die vaderlike liefde wat hulle ontsê is, soek hulle dan by ander mans (vgl. Green, 1976; Holborn \& Eddy, 2011; Nielsen, 2011). Die literatuur beklemtoon dat vaderlose adolessente meisies op 'n jonger ouderdom seksueel aktief raak as meisies met betrokke vaders en dat hulle romantiese verhoudings meer geneig is om onstabiel te wees (Grainger, 2004; Nielsen, 2011).

\section{Tema 4: Emosionele impak}

Freeks (2004) en Adams et al. (1984) maak melding daarvan dat vaderlose kinders dikwels met gevoelens van vrees, eensaamheid, depressie, ontevredenheid en vervreemding worstel. Hulle is meer geneig om depressief te raak as dogters met hegte verhoudings met hul vaders (Holborn \& Eddy, 2011; Nielsen, 2011). Gevoelens van vervreemding, woede, verwerping en minderwaardigheid is die hoofgevoelens wat uit die individuele onderhoude na vore gekom het.

Subtema 4.1: Voel soos 'n buitestaander: Dit wil voorkom of die deelnemers as gevolg van hul vaders se onbetrokkenheid "anders" voel as ander dogters van hul ouderdom. Dit voel vir hulle asof hulle iets wat ander dogters van hul ouderdom het, mis. Baie van die deelnemers noem dat hulle hartseer raak wanneer hulle hul vriende saam met hul vaders sien. Dit voel vir hulle asof dit die norm is om 'n vader te hê. Hier volg 'n paar opmerkings wat uit die onderhoude na vore gekom het:

C: "Ek voel altyd eenkant wanneer my vriende praat oor hul pa's."

D: "I feel sad each time when I see my friends with their dads."

Subtema 4.2: Woede: Op die vraag: "As jy nou iets vir jou pa kon sê, wat sou jy sê?" antwoord 'n paar van die deelnemers soos volg:

D: "Nothing, I'm too angry about the things he did to my family ... Why did you leave us? Why did you beat my mother? Why can't you stop drinking and all those abusive things?"

F: "Why did you leave us?..I'll tell him that I'm angry that he doesn't want to be involved in my life."

Uit die deelnemers se opmerkings is dit duidelik dat 'n groot persentasie van die deelnemers woede teenoor hul biologiese vaders ervaar. Dit voel vir hulle asof hulle biologiese vaders hulle 'n onreg aangedoen het. Daar is twee groeplede wat genoem het dat hulle dit moeilik vind om hul biologiese vaders te vergewe. Nielsen (2011) stel dat adolessente meisies meer geneig is om woede teenoor hul afwesige vaders te beleef as adolessente seuns. As jong volwassenes mag hul dit moeiliker vind om hul woede effektief te bestuur as vrouens wat grootgeword het met 'n hegte vaderlike band.

Subtema 4.3: Gevoel van verwerping: Uit die navorsingsonderhoude blyk dit duidelik dat die deelnemers verwerp voel, wat toegeskryf kan word aan hul vaders se afwesigheid. Hier volg 'n paar opmerkings wat uit die onderhoude na vore gekom het en wat bogenoemde stelling bevestig:

A: "Ek voel nie dat hy (biologiese vader) oor my worry nie. Het nog altyd gevoel asof hy nie vir my omgee nie."

C: "My ma het net altyd gesê hy (biologiese vader) is besig en wil ons nie sien nie. Ons moet aangaan en vergeet dat ons 'n pa het ... Hy wil niks van ons weet nie."

Op die vraag: "As jy nou iets vir jou pa kon sê, wat sou jy sê?" het van die deelnemers die volgende geantwoord:

C: "Hoekom wil jy nie saam met ons wees nie?"

D: "Why did you leave us?"

Dit is duidelik dat die deelnemers ervaar dat hul biologiese vaders hulle verlaat het. Dit het vanselfsprekend 'n nadelige impak op hul selfbeeld en gevoel van eiewaarde. Vaderlose adolessente dogters is aansienlik meer geneig om verwerp en ongeliefd te voel as vaderlose adolessente seuns (Nielsen, 2011).

Subtema 4.4: Minderwaardigheidsgevoel: Die feit dat die deelnemers 'n gevoel van verwerping ervaar, het indirek 'n nadelige effek op die ontwikkeling van hul selfbeeld. Party van die deelnemers voel dat hulle vaders se afwesigheid meebring dat hulle lewens minder waarde het. Hier volg opmerkings van twee van die deelnemers wat hierdie stelling bevestig:

C: "Gevoel dat hoekom moet ek op aarde gelewe het as ek net 'n enkelouer het en 'n pa wat niks met ons te doen wil hê nie."

F: "He (father) doesn't treat his children equally ... I feel that I'm less important than the others (her father's other children)."

Tema 5: Negatiewe impak op identiteitsvorming

Adolessensie is 'n tydperk waarbinne jongmense hul persoonlike identiteit vestig. Hulle dink na oor wie hulle is en oor wat hulle wil word. Hulle besluit oor die doelwitte, waardes en oortuigings wat vir hulle belangrik is (Papalia et al. 2009; Zastrow \& Kirst-Ashman, 2013). Kinders het behoefte daaraan om meer te weet van wat in hul vaders se lewens gebeur. Hulle is nuuskierig oor hul vaders se opvattings en gevoelens. (vgl. Green, 1976; Freeks, 2004).

Uit die onderhoude wat met die deelnemers gevoer is, wil dit voorkom of adolessente dogters wat sonder ' $n$ vader grootgeword het, dit moeiliker vind om hul persoonlike identiteit te vestig. Een deelnemer noem op verskillende tye gedurende die onderhoud dat sy graag meer wou geweet het van die tipe persoon wat haar vader is en dat sy graag sy mening wou hoor oor die dinge wat sy doen. Hier volg ' $n$ paar opmerkings van die spesifieke deelnemer:

A: "Hy (biologiese vader) moet sê wat hy van my verwag." 

het."

"Ek wonder wat my pa daarvan sal sê dat ek 'n boyfriend

Deelnemer C sou graag die volgende vraag aan haar biologiese vader wou stel:

"Wie is jy?"

'n Paar deelnemers is van mening dat dit vir hulle makliker sou gewees het om hulleself te verstaan as hulle geweet het watter tipe persoon hul vader is.

Tema 6: Verhouding met seuns/mans

Op die vraag: "Wat het dit aan jou gedoen dat jou pa onbetrokke in jou lewe was?" antwoord een van die deelnemers die volgende:

B: "Ek voel teruggetrokke. Ek wil nou net by my ma en my ouma wees; nie by mans nie."

Dit wil voorkom of hierdie deelnemer, as gevolg van haar pa se onbetrokkenheid, haar meer van mans in die algemeen afsonder. Sy noem dat sy dit moeilik vind om met mans te kommunikeer.

Op die vraag: "Vertel my 'n bietjie meer van jou verhouding met seuns," antwoord 'n paar van die deelnemers soos volg:

C: "Ek kom goed met hulle oor die weg. Almal is nie dieselfde nie. Dit beteken nie dat hulle ook eendag afwesig in hul kinders se lewens sal wees nie."

F: "I have a boyfriend, we respect each other. I can relate to him; we understand each other."

Dit wil voorkom of die meerderheid deelnemers in staat is daartoe om gesonde verhoudings met seuns op te bou. Die indruk word dus verkry dat hul vaders se afwesigheid nie 'n nadelige effek op hul verhoudings met seuns het nie. Beskikbare literatuur weerspreek egter hierdie stelling. Holborn en Eddy (2011) is van mening dat 'n liefdevolle verhouding met ' $n$ vader ' $n$ dogter beter toerus om gesonde verhoudings met mans op te bou. Dogters wat alleen saam met vroulike familielede grootword, het ' $n$ duidelike idee van hul eie magte as vrouens, maar het nooit geleer hoe die teenoorgestelde geslag lewe nie (vgl. Freeks, 2004; Green, 1976).

Tema 7: Betrokkenheid van biologiese moeder

Op die vraag: "Hoe betrokke is jou ma in jou lewe?" antwoord die deelnemers soos volg:

A: "My ma maak op vir my pa. Sy sê altyd dat sy die beste vir my toekoms wil hê."

B: "As ons siek is, is sy daar. As ons goete nodig het, probeer sy haar bes om ons gelukkig te hou."

F: "She helps me with anything. She's my friend, I can tell her anything."

Uit bostaande aanhalings blyk dit duidelik dat die deelnemers se biologiese moeders deels vergoed vir die afwesigheid van hul biologiese vaders. Die biologiese moeders is betrokke in hul dogters se lewens en is besorg oor hul dogters se psigososiale welstand. Daar kan afgelei word dat ander gesinslede deels kan vergoed vir die leemte wat ' $n$ afwesige vader agterlaat. Sommige van die deelnemers het melding gemaak daarvan dat daar ander persone in hul lewens is wat ' $n$ vaderlike rol teenoor hulle vervul.

\subsection{Fase 2}

Die navorser het vraelyste aan 30 adolessente meisies wat sonder die betrokkenheid van 'n biologiese vader grootgeword het, gegee om ingevul te word. Graad 10 en 11 swart en Kleurling meisies is uitgenooi om die vraelys te voltooi. Hulle was tussen die ouderdom van 16 en 18 jaar en van ' $n$ lae sosio-ekonomiese klas. Die statistiese data wat deur die tweede fase van die navorsing ingewin is, word vervolgens weergegee.

Daar is bevind dat $76.67 \%$ (23 uit 30 proefpersone) van die ondersoekgroep iemand in hul lewens het wat 'n vaderlike rol teenoor hulle vervul. Die persone wat 'n vaderlike rol teenoor hierdie proefpersone vervul, word in Tabel 1 gelys:

Uit Tabel 2 is dit duidelik dat die stiefpa die persoon is wat meestal ' $n$ vaderlike rol teenoor vaderlose dogters vervul.

Die ondersoekgroep dui die volgende oorsake van hul vaders se afwesigheid aan:

Egskeiding/skeiding - 46.7\%

Dood - 30\%

My pa woon saam met ons, maar is onbetrokke op 'n emosionele vlak - $13.3 \%$

'n Hofbevel wat kontak tussen my en my vader verbied - $6.7 \%$ Ander $-3.3 \%$

Uit die ondersoekgroep noem $63.3 \%$ dat dit vir hul biologiese vaders moontlik is om meer betrokke in hul lewens te wees, terwyl $36.7 \%$ aandui dat dit nie vir hulle moontlik is nie.

Die proefpersone se antwoorde op die vyfpuntskaal-vrae kan soos volg opgesom word:

Uit Tabel 3 en Figuur 3 is dit duidelik dat die proefpersone se ma's vergoed vir hul vaders se onbetrokkenheid. ' $n$ Groot persentasie is van mening dat die lewe makliker vir hul ma's sou gewees het as hul pa's betrokke was in hul lewens. 'n Groot persentasie wil hê dat hul vaders moet erken dat hulle (die dogters) hul dogters is. Dit lyk nie asof hul vaders se onbetrokkenheid ' $n$ nadelige effek op die proefpersone se gevoel van eiewaarde het nie.

Tabel 2 - Persone wat 'n vaderlike rol vervul.

\begin{tabular}{lc} 
Persoon & $\begin{array}{l}\text { Persentasie proefpersone wat aandui } \\
\text { dat hierdie persoon 'n vaderlike rol } \\
\text { teenoor haar vervul: }\end{array}$ \\
\hline Stiefpa & $39.1 \%$ \\
Oom & $21.7 \%$ \\
Biologiese moeder & $13 \%$ \\
Broer & $8.7 \%$ \\
Ander & $17.4 \%$ \\
\hline
\end{tabular}


Tabel 3 - Vyfpuntskaal-vrae.

\begin{tabular}{|c|c|c|c|c|c|}
\hline & $\begin{array}{c}\text { Stem } \\
\text { heeltemal } \\
\text { saam }\end{array}$ & $\begin{array}{l}\text { Stem } \\
\text { saam }\end{array}$ & Onseker & $\begin{array}{c}\text { Stem nie } \\
\text { saam } \\
\text { nie }\end{array}$ & $\begin{array}{c}\text { Stem } \\
\text { glad nie } \\
\text { saam nie }\end{array}$ \\
\hline My ma maak op vir my pa se onbetrokkenheid & $60 \%$ & $13.3 \%$ & $3.3 \%$ & $16.7 \%$ & $6.7 \%$ \\
\hline Ek voel verlore en rigtingloos & $16.7 \%$ & $26.7 \%$ & $16.7 \%$ & $20 \%$ & $20 \%$ \\
\hline Dit voel asof ek uitmis op iets wat ander dogters het & $40 \%$ & $26.7 \%$ & $10 \%$ & $6.7 \%$ & $16.7 \%$ \\
\hline $\begin{array}{l}\text { As gevolg van my vader se onbetrokkenheid voel dit asof my } \\
\text { lewe minder waarde het }\end{array}$ & $16.7 \%$ & $20 \%$ & $16.7 \%$ & $23 \%$ & $23 \%$ \\
\hline $\begin{array}{l}\text { Ek het vrede daarmee gemaak dat my pa nooit betrokke in } \\
\text { my lewe sal wees nie }\end{array}$ & $40 \%$ & $26.7 \%$ & $10 \%$ & $20 \%$ & $3.3 \%$ \\
\hline Ek wil hê dat my vadermoet erken dat ek sy dogter is & $53 \%$ & $33 \%$ & $3 \%$ & $3 \%$ & $7 \%$ \\
\hline Ek wil weet watter tipepersoon my vader is/was & $37 \%$ & $27 \%$ & $20 \%$ & $7 \%$ & $10 \%$ \\
\hline Ek voel soos 'n buitestaander wanneer my vriende oor hul pa's praat & $40 \%$ & $23 \%$ & $17 \%$ & $10 \%$ & $10 \%$ \\
\hline $\begin{array}{l}\text { Die lewe sou makliker vir my ma gewees het as my pa betrokke } \\
\text { in ons lewens was }\end{array}$ & $57 \%$ & $20 \%$ & $10 \%$ & $7 \%$ & $7 \%$ \\
\hline
\end{tabular}

Die antwoorde op die graderingvraag wat gehandel het oor dít wat die proefpersone die graagste van hul vaders wou gehad het, kan soos volg voorgestel word:

Uit Tabel 4 en Figuur 4 blyk dit dat die behoefte om te hoor dat hul vaders lief is vir hulle, die sterkste by die ondersoekgroep na vore gekom het. Die proefpersone het verder sterk behoefte daaraan dat hul vaders 'n positiewe rolmodel vir hulle moet wees.

Die mees ondersteunende persoon in die proefpersone se lewens kan soos volg voorgestel word:

Uit Figuur 5 is dit duidelik dat die proefpersone se moeders die mees ondersteunende persoon in hul lewens is. Hul kêrels en stiefpa's speel in mindere mate ' $\mathrm{n}$ ondersteunende rol in hul lewens.

Die belangrikste rol wat ' $n$ vader, volgens die proefpersone, vervul, kan soos volg voorgestel word:

Uit Figuur 6 is dit duidelik dat die proefpersone in 'n groot mate voel dat dit vaders se taak is om hulle dogters oor seuns in te lig. Hulle meen dat vaders hul dogters moet help om goeie keuses in hul lewens te maak. Die verskaffing van spirituele leiding en die bied van geselskap aan hul dogters het die swakste voorgekom.

\section{Bespreking}

$\mathrm{Na}$ aanleiding van die bevindinge is dit duidelik dat adolessente dogters wat sonder ' $\mathrm{n}$ pa grootword, besorg is oor die hoeveelheid spanning wat hul biologiese moeders op ' $n$ daaglikse basis ondervind. Die twee groepe deelnemers noem dat hul biologiese moeders ' $n$ groot hoeveelheid verantwoordelikhede dra. Die literatuur beklemtoon die feit dat enkelma's dikwels oorlaai en uitgebrand voel aangesien hulle nou al die versorgingsverantwoordelike self moet dra en meer finansiële spanning beleef (Sieber, 2008). Wieman, Agurcia, Rickert, Berenson en Volk (2006) voer aan dat moeders meer effektief in hul ouerskapstaak is wanneer hulle sterk sosiale en emosionele ondersteuning van hul familie en die kind se vader ontvang. Vaders verskaf beide ekonomiese en sosiale kapitaal wat bydra tot adolessente dogters se akademiese prestasie, selfvertroue en die kwalitieit van hul portuurverhoudings (Krampe \& Newton, 2006).

Dit wil voorkom of vaderlose, adolessente dogters ' $n$ groot aantal onvervulde behoeftes het wat aan die afwesigheid van hul biologiese vaders toegeskryf kan word. Die

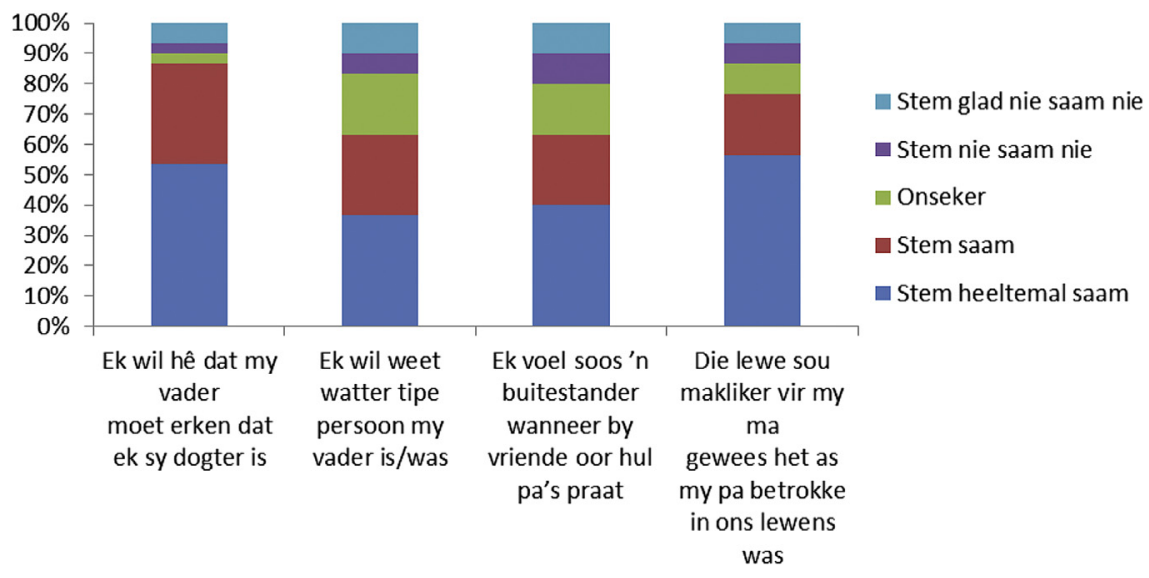

Figuur 3 - Vyfpuntskaal-vrae. 
Tabel 4 - Behoefte aan ' $n$ vader.

\begin{tabular}{|c|c|c|c|c|}
\hline & $\begin{array}{l}\text { Rangorde: } \\
1 \text { of } 2\end{array}$ & $\begin{array}{l}\text { Rangorde: } \\
3 \text { of } 4\end{array}$ & $\begin{array}{l}\text { Rangorde: } \\
5-8\end{array}$ & $\begin{array}{l}\text { Rangorde: } \\
9 \text { of } 10\end{array}$ \\
\hline Ek wil hê my pa moet my meer vertel van die wêreld & $30 \%$ & $13 \%$ & $30 \%$ & $27 \%$ \\
\hline Ek wil hê my pa moet my leer wat reg en verkeerd is & $20 \%$ & $20 \%$ & $47 \%$ & $13 \%$ \\
\hline Ek wil my pa se mening hoor oor die dinge wat ek doen & $17 \%$ & $20 \%$ & $53 \%$ & $10 \%$ \\
\hline Ek wil hê my pa moet my vertel dat hy lief is vir my & $40 \%$ & $30 \%$ & $17 \%$ & $13 \%$ \\
\hline Ek wil hê dat my pa 'n positiewe rolmodel vir my moet wees & $33 \%$ & $20 \%$ & $43 \%$ & $3 \%$ \\
\hline $\begin{array}{l}\text { Ek wil hê dat my pa my moet beskerm teen die mense wat 'n } \\
\text { slegte invloed op my lewe het }\end{array}$ & $20 \%$ & $20 \%$ & $57 \%$ & $3 \%$ \\
\hline Ek wil net my pa se teenwoordigheid voel & $17 \%$ & $20 \%$ & $57 \%$ & $7 \%$ \\
\hline Ek wil my probleme met my pa deel & $7 \%$ & $30 \%$ & $43 \%$ & $20 \%$ \\
\hline Ek wil hê dat my pa my moet motiveer & $17 \%$ & $13 \%$ & $53 \%$ & $17 \%$ \\
\hline
\end{tabular}

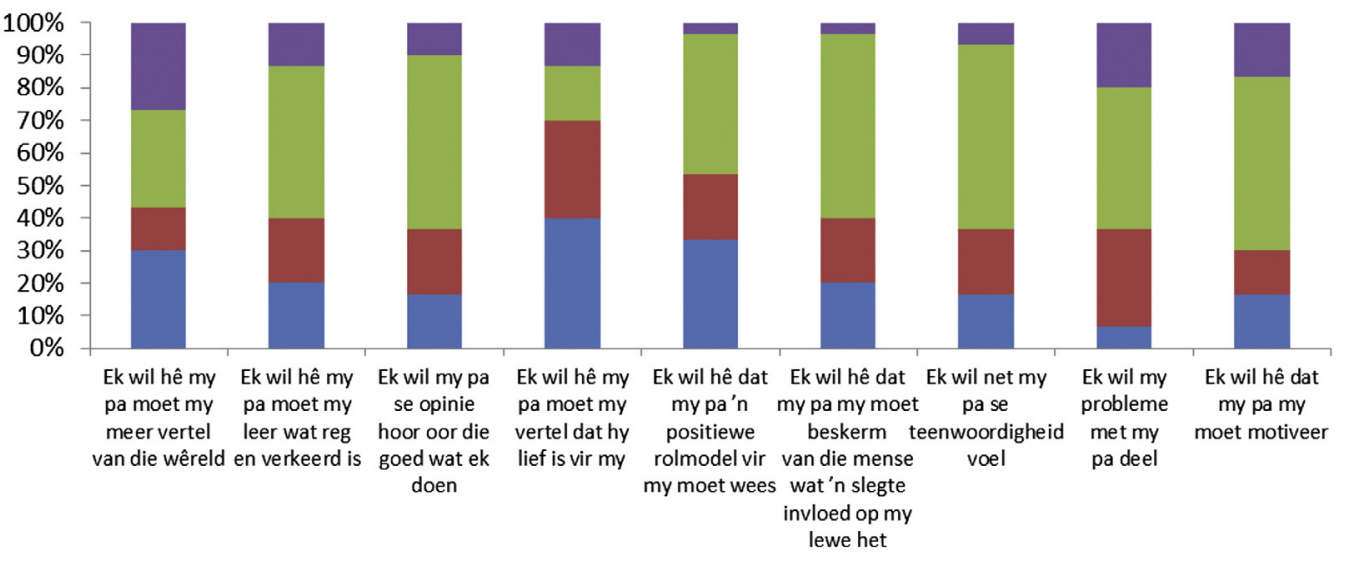

Ranking: 1 of $2 \square$ Ranking: 3 of $4 \quad$ Ranking: 5-8 $\square$ Ranking: 9 of 10

Figuur 4 - Behoefte aan 'n vader.

deelnemers maak melding daarvan dat hulle graag 'n verhouding met hul vaders wil hê. Onder die emosionele behoeftes blyk dié aan erkenning die sterkste te wees. Dit is duidelik dat adolessente dogters leiding van hul vaders verlang. Die deelnemers tydens Fase 1 noem dat dit ' $n$ vader se taak is om sy dogter meer te vertel van die wêreld en van seuns terwyl $30 \%$ van deelnemers tydens Fase 2. van mening is dat dit die belangrikste rol van vaders is. Die deelnemers

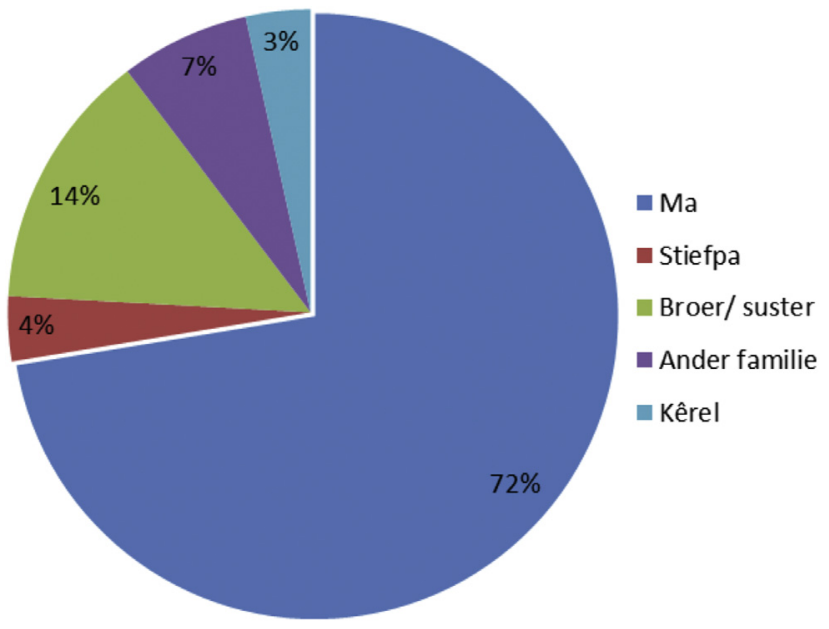

Figuur 5 - Ondersteuningsisteem. tydens Fase 1 noem dat hulle sterk behoefte het aan 'n vader se teenwoordigheid. Van die proefpersone tydens Fase 2 noem $43.3 \%$ dat hulle na hulle vaders se teenwoordigheid smag. Die literatuur beklemtoon die feit dat vaderlose meisies dikwels worstel met gevoelens van verlange en dat hulle smag na die betrokkenheid van 'n vader (Sieber, 2008; Wineburgh, 2000). Hulle mag verantwoordelik voel vir die afwesigheid van hul vader en is meer geneig tot depressie (Wineburgh, 2000).

Die afwesigheid van hul vaders het negatiewe emosionele implikasies by die deelnemers/proefpersone tot gevolg. Slegs $6.7 \%$ van die deelnemers uit Fase 2 noem dat hulle ongeraak is deur die afwesigheid van hul biologiese vaders. Uit die individuele onderhoude tydens Fase 1 het die tema van verwerping sterk uitgestaan. Aan die ander kant het slegs $33.3 \%$ van die deelnemers tydens Fase 2 aangedui dat hulle verwerping van hul biologiese vaders beleef. Die literatuur beklemtoon dat vaderlose kinders dikwels in hul eie vermoëns twyfel, onseker voel en hulself blameer vir hul vaders se onbetrokkenheid in hul lewens (Wineburgh, 2000). Hul selfbeeld word dikwels negatief geraak deur die afwesigheid van hul vader en hulle is dikwels oortuig dat hul vader 'n negatiewe opinie van hul het (Sieber, 2008). Hierdie kinders worstel dikwels met gevoelens van minderwaardigheid (Wineburgh, 2000) en voel verwerp en ongeliefd (Nielsen, 2011). 


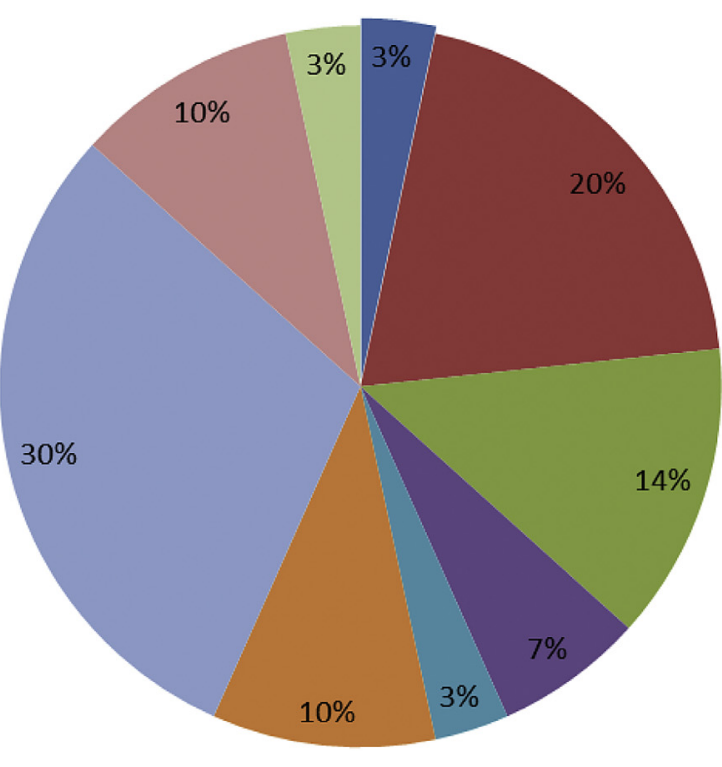

Spirituele leiding

Om hulle dogters te help om goeie keuses te maak

$\square$ Om die familie finansieël te onderhou

- Om gesonde waardes vir hul dogters te leer

- Om geselskap aan hul dogters te verskaf

$\square$ Om die hoeveelheid stres in die ma se lewe, te verlig

$\square$ Om hul dogters in te lig oor seuns

- Om vir hul dogters te wys wat dit beteken om deur 'n man lief gehê te word

Ander

Figuur 6 - Die rol van 'n vader.

Die deelnemers noem dat hulle "anders" voel as ander dogters van hul ouderdom. 66.7\% van die deelnemers uit Fase 2 stem saam met die stelling dat dit voel asof hulle iets wat ander dogters het, ontsê word.

Dit is duidelik dat die deelnemers nuuskierig is oor die tipe persoon wat hul vaders is/was. $64 \%$ van die deelnemers uit Fase 2 wil weet watter tipe persoon hul vader is/was. Wineburgh (2000) stel dat vaderlose kinders dikwels met onopgeloste vrae worstel byvoorbeeld: "Wie is my pa?" "Deel ek ooreenkomste met hom?" "Wat is sy etniese-en geloofsagtergrond?" "Hoekom wys my pa geen belangstelling in my nie?"

Alhoewel dit duidelik blyk dat daar ander persone in die deelnemers/proefpersone se lewens is wat vergoed vir hul vaders se onbetrokkenheid, kan daar afgelei word dat vaderlose adolessente dogters steeds behoefte het aan hul vaders se teenwoordigheid. Die feit dat hul vaders onbetrokke is in hul lewens het negatiewe implikasies tot gevolg. Slegs $6.7 \%$ is ongeraak deur hul vaders se onbetrokkenheid in hul lewens. Dit wil voorkom asof die betrokkenheid van 'n vader 'n positiewe impak het op kinders se geluk, lewenstevredenheid en emosionele regulering (King, Widaman, Cauce, \& Conger, 2011).

\section{Leemtes}

'n Leemte binne hierdie studie is die feit dat die deelnemers net van een hoërskool afkomstig was. Meer navorsing waar verskeie skole betrek word, behoort gedoen te word.

\section{Aanbevelings}

Daar word sterk aanbeveel dat welsynsorganisasies ter aanvulling van hul vaderskapsprogramme gebruik moet maak van die bevindinge van hierdie studie. Die data wat deur hierdie studie ingesamel is, sal vaders help om ' $n$ beter idee te kry van hul waarde in hul adolessente dogters se lewens. Dit mag vaders moontlik aanmoedig om meer betrokke te raak in hul kinders se lewens.

Aangesien hierdie studie op 'n klein skaal geskied het, behoort daar veel meer navorsing op hierdie gebied op groot populasies uitgevoer moet word.

\section{Gevolgtrekking}

Ten slotte is dit duidelik dat vaders ' $n$ belangrike rol in hul adolessente dogters se lewens speel. Vaders het verskeie rolle om te vervul. Hulle is nie net daar vir finansiële bystand nie. Hulle dogters het behoefte daaraan om 'n verhouding met hulle op te bou en om kwaliteittyd saam met hulle deur te bring. Adolessente dogters benodig liefde, hartlikheid, aandag en erkenning van hul vaders. Die rol en waarde van ' $n$ pa kan dus nie in een-dimensionele terme gesien word nie. Vaders is sorgverskaffers, vriende, modelle en mentors vir hulle dogters.

\section{R E F E R E N C E S}

Adams, P. L., Milner, J. R., \& Schepe, N. A. (1984). Fatherless children. New York: John Wiley.

Almond, B. (2006). The fragmented family. New York: Claredon Press.

Bartlett, E. R., \& (Huweliks- en gesinsterapeut). (2013). Impak van afwesige vaders op tiener meisies [persoonlike onderhoud]. Johannesburg: 19 Mei.

Chideya, Y., \& Williams, F. (2013). Adolescent fathers: exploring their perceptions of their role as parent. Social Work/ Maatskaplike Werk, 49(2), 209-221.

Collins, D., Jordan, C., \& Coleman, H. (2010). Family social work. Belmont: Brooks/Cole. 
Creswell, J. W., \& Plano Clark, V. L. (2007). Designing and conducting mixed methods research. London: SAGE.

Cruz, R. A., King, K. M., Widaman, K. F., Leu, J., Cauce, A., \& Conger, R. D. (2011). Cultural influences on positive father involvement in two-parent Mexican-origin families. Journal of Family Psychology, 1-10.

Delport, C. S. L. (2005). Quantitative data-collection methods. In A. S. De Vos (Ed.), Research at grass roots: For the social sciences and human service professions (pp. 159-191). Pretoria: Van Schaik Publishers.

Delport, C. S. L., \& Fouche, C. B. (2011). Mixed methods. In A. S. De Vos (Ed.), Research at grass roots: For the social sciences and human service professions (pp. 433-448). Pretoria: Van Schaik Publishers.

Dinkmeyer, D., Mckay, G. D., Mckay, J. L., \& Dinkmeyer, D. (1998). Parenting teenagers. New York: STEP.

DuBois, B., \& Miley, K. K. (2010). Social work: An empowering profession. Boston: Pearson Education.

Fagan, J., Palkovitz, R., Roy, K., \& Farrie, D. (2009). Pathways to paternal engagement: longitudinal effects of risk and resilience on nonresident fathers. Development Psychology, 45(5), 1389-1405.

FAMSA Potchefstroom. (2012). In Algemene jaarvergadering 21 Augustus 2012 (Ongepubliseerd).

Ford, J., Nalbone, D. P., Wetcher, J. L., \& Sutton, P. M. (2008). Fatherhood: how differentiation and identity status affect attachment to children. American Journal of Family Therapy, 36(4), 284-299.

Freeks, F. E. (2004). Die rol van die ontbrekende vaderfiguur in die SuidAfrikaanse konteks: 'n prakties-teologiese studie. MA dissertation. Potchefstroom: Dept. of Theology, PU vir CHO.

Freeks, F. E. (2011). The role of the father as mentor in the transmission of values: A pastoral-theological study. PhD thesis. Potchefstroom Campus: Dept. of Theology, North-West University.

Freeks, F. E. (2013). Dad is destiny: The man god created to be. Potchefstroom: Ivyline Technologies.

Freeks, F. E., \& Lotter, G. A. (2009). 'n Prakties-teologiese ondersoek na die uitwerking van afwesige vaders: ' $n$ verkennende kwalitatiewe ondersoek in die Promosagemeenskap. Koers, 74(3), 519-534.

Gaskell, G. (2000). Individual and group interviewing: Qualitative researching with text, image and sound. London: SAGE.

Goodsell, T. L., \& Meldrum, J. T. (2010). Nurturing fathers: a qualitative examination of child-father attachment. Early Child Development and Care, 180(1 \& 2), 249-262.

Grainger, S. (2004). Family background and female sexual behaviour: a test of the father-absence theory in Merseyside. Human Nature, 15(2), 133-145.

Greeff, M. (2011). Information collection: interviewing. In A. S. De Vos, H. Strydom, C. B. Fouché, \& C. S. L. Delport (Eds.), Research at grass roots: For the social sciences and human service professions (pp. 341-375). Pretoria: Van Schaik Publishers.

Green, M. (1976). Goodbye father. London: Routledge \& Kegan Paul.

Handwoordeboek van die Afrikaanse taal (HAT). (1994). 3de uitg. Midrand: Perskor.

Holborn, L., \& Eddy, G. (2011). First steps to healing the South African family. Johannesburg: South African Institute of Race Relations.

Ivankova, N. V., Creswell, J. W., \& Plano Clark, V. L. (2007). Foundations and approaches to mixed methods research. In K. Maree (Ed.), First steps in research (pp. 255-282). Pretoria: Van Schaik Publishers.
King, K. M., Widaman, K. F., Cauce, A. M., \& Conger, R. D. (2011). Cultural influences on positive father involvement in twoparent Mexican-origin families. Journal of Family Psychology, 25(5), 731-740.

Krampe, E. M., \& Newton, R. R. (2006). The father presence questionnaire: a new look measure of the subjective experience of being fathered. A Journal of Theory, Research and Practice About Men As Fathers, 4(2), 159-190.

Lamb, M. E. (2010). The role of the father in child development (5th ed.). New Jersey: John Wiley \& Sons.

Madhavan, S., Townsend, N. W., \& Garey, A. I. (2008). Absent breadwinners: father-child connections and paternal support in rural South Africa. Journal of South African Studies, 34(3), 647-663.

Mandara, J., Murray, C. B., \& Joyner, T. N. (2005). The impact of fathers' absence on african american adolescents' gender role development. Sex Roles, 53(3/4), 207-220.

Monette, D. R., Sullivan, T. J., \& DeJong, C. R. (2008). Applied social research: A tool for the human services. New York: Cengage.

Nielsen, L. (2011). Divorced fathers and their daughters: a review of recent research. Journal of Divorce and Remarriage, 52(2), 77-93.

Nieuwenhuis, J. (2007a). Qualitative research designs and data gathering techniques. In K. Maree (Ed.), First steps in research (pp. 70-97). Pretoria: Van Schaik Publishers.

Nieuwenhuis, J. (2007b). Analysing qualitative data. In K. Maree (Ed.), First steps in research (pp. 99-117). Pretoria: Van Schaik Publishers.

Oelofse, M., \& (Direkteur - Famsa Potchefstroom). (2013). Mites rondom vaderskap [persoonlike onderhoud]. Potchefstroom: 22 Maart.

Pacholok, S., \& Gauthier, A. (2010). Non-participant fathers in time-use studies: uninvolved or data artifact. Social Indicators Research, 96(2), 249-266.

Papalia, D. E., Olds, S. W., \& Feldman, R. D. (2009). Human development. New York: McGraw-Hill.

Pietersen, J., \& Maree, K. (2007). Statistical analysis I: descriptive statistics. In K. Maree (Ed.), First steps in research (pp. 182-196). Pretoria: Van Schaik Publishers.

Sieber, D. (2008). Engaging absent fathers in the treatment of children. Clinical Social Work Journal, 36, 333-340.

Smit, R. (2004). Involved fathering: expanding conceptualisations of men's paternal caring. Koers, 69(1), 101-120.

South African Institute of Race Relations (SAIRR). (2013). Black economic empowerment. Johannesburg: SAIRR.

Steyn, A. F. (1993). Family structures in R.S.A. Pretoria: HSRC.

Steyn, R. S., \& Lotter, G. A. (2006). Voorhuwelikse verhoudings: 'n verkennende kwalitatiewe empiriese ondersoek. Praktiese Teologie in Suid-Afrika, 21(1), 104-120.

Strydom, H. (2005). Ethical aspects of research in the social sciences and human service professions. In A. S. De Vos (Ed.), Research at grass roots: For the social sciences and human service professions (pp. 56-70). Pretoria: Van Schaik Publishers.

Van Wormer, K., \& Davis, D. R. (2008). Addiction treatment. Belmont: Brooks/Cole.

Wieman, C. M., Agurcia, C. A., Rickert, V. I., Berenson, A. B., \& Volk, R. J. (2006). Absent fathers as providers: race/ethnic differences in support for adolescent mothers. Child and Adolescent Social Work Journal, 23(5-6), 617-634.

Wineburgh, A. L. (2000). Treatment of children with absent fathers. Child and Adolescent Social Work Journal, 17(4), 255-273.

Zastrow, C. H., \& Kirst-Ashman, K. K. (2013). Understanding human behavior and the social environment. Belmont: Brooks/Cole. 